\title{
Introducing a Gennext Banking with a Direct Banking Solution
}

\author{
Mrs. Sowjanya Lakshmi A, Dr.B.S.Pradeep
}

Abstract: Banking Industry is competing with the current Enterprise Industry using advanced Technology. Technology evolved from ATM till core banking solutions. Later revolution in technology came with online banking, mobile banking solutions. Involvement of Technology in Banking Industry is improving customer relationship and also preventing customers from waiting in long queues. This paper proposes Direct Banking Solutions to facilitate customer with 'Anytime Anywhere Banking'.

Keywords: Direct Banking, Next Generation Banking, Core Banking Solution, Banking Delivery Channels, Branchless Banking, SOEA, Business services.

\section{Introduction}

The digital lifestyle and the technological revolution are in demand at homes and at the workplace, which host new challenges to the finance sector, specially banking industry. In an attempt to satisfy such demands, banks optimize their services, minimize costs and migrating towards a $24 \times 7$ services and customers are enjoying the greater sense of freedom.

The customers want a great banking service which satisfies their requirements on time. Of course Core Banking Solution (CBS), which made "Branch customer to Bank customer", but, still CBS does not manages with cost of small transactions, successful and unsuccessful transactions, customer relationship management and decision making and moreover, CBS is employee-centric Solution, not Customer-centric Solution. Thus, there is a need to think beyond CBS. [4]

In this era of new expectations, $48 \%$ of customers around the world planning to change banks because of general levels of services and $43 \%$ because of costs and product offerings. Also Most of the customers are happy with personalized services. According to recent survey, $83 \%$ of customers satisfied with internet banking, $79 \%$ with ATMs and $79 \%$ with branches. [12] This survey says that, customers are more satisfied with branchless banking than visiting branches. "The GenNext customer is very busy, to go branch, wait for his turn to open an account, for transactions and for other banking". But, still only $30 \%-40 \%$ of banking is branchless, rest is under the control of branch.

Supported by the latest technology, banks would need to identify new business niches, to develop customized services and to implement innovative strategies. Of course with this implementation, not only bank customers are retained, but also, new customers are attracted.

Banking is an enterprise that consists of various lines of business like retail, business banking and commercial lines of business. The scope of the paper is with respect to retail banking.

\section{Current Technology In Banking Industry}

Technology has introduced many concepts and strategies in the banking industry over the years.

The major technological innovation in banking was the ATM over 25 years ago, and up until the early 1990s this was the only customer-facing technology that existed. Now, there have been more changes in this sphere in the last 10 to 15 years. [2] Then, banks have implemented CBS which made 'branch customers to bank customers'.

- ATM, internet banking and mobile banking have improved customer convenience by providing anywhere anytime banking services. The utility bill presenting and payment has helped customers to pay their bills online at the click of a button.

- Electronic clearing system and electronic fund transfer have facilitated faster funds movement and settlement for the customers of different banks and different branches.

- The electronic data interchange and cash management service facilities have enabled better fund management for the customer.

- Banks also offer customers the ability to access their accounts and perform at least simple money transactions using internet banking, mobile banking. But, still internet banking is not fully personalized; all the customers will be provided with same windows and services. Hence, if the services and products selection is made according to the customer requirement, using needs assessment approach (Discussed in Section III), then customer is benefited and enjoys banking sophisticatedly and bank retains customer. [4][9] 
Though, banking business processes are automated due to the enforcement of RBI guidelines, in reality it is much lower, as many functions in each branch are still done manually or with partial automation.

Also, present Banking Technology / Solution don't allow any prospect even to open an account without visiting branch.

- Based on Web1.0, traditional internet banking provides poor user experience. Operations require a full-screen refresh, which takes a long time. They don't have the integrated view and one-stop service which customer can find in other versions of Web-based applications. [4]

Hence, the concepts of Next Generation Banking are taking centre stage. There is a need to fast forward to banking 2.0. [2] Generations in Banking Enterprise Solutions is depicted in figure 1.

Currently, many business applications are based on Web2.0 and Web 3.0 concepts and technologies. Also, financial data with GPS technology enable banks to provide value-added services. [3]

The proposed enterprise architecture of Direct Banking Solution, in the top layer identifies; [6] [1]

- Business processes landscape

- A business component, provides a set of services out of a given business domain

- Business services in each business processes

- Composite business services landscape

- Wide variety of delivery channels of direct banking

- Maintenance strategy of direct banking

- Business, technology, data and application architecture design and implementation

\section{Next Activity:}

This paper is introducing Direct Banking Solution, business processes and business services involved in it, also different delivery channels through which Direct Banking can be accessed. This paper also puts light on the current technology which is used in banking industry. The design and implementation of new business processes and services and their business and technology architecture is out of scope, which is future scope of this paper.

\section{Next Generation Banking - A Direct Banking Solution}

"Banking is necessary but banks are not", says Bill Gates.

The Next Generation Banking aims to provide customer-centric features. In customer-centric solution, the customer is identified as a bank customer for all line of business, giving users an extremely personalized, increased intelligence and automation to help banks sell appropriate products and services to their customers. [2] But, in employee-centric solution like CBS, customer is having a restricted identification in a particular line of business and in other line of business; the individual is a prospect, but not a customer.

"Banks can initiate innovative products that offer higher returns such as multi-currency deposits, product bundles, customer rewards and relationship pricing". [7]

Needs Assessment approach, product bundling approach are new strategies which are evolving to make customer more convenient with his requirement and also bank to make intelligent decision in rendering products and services at lower cost to customer and profitable cost to bank. For this the service level multi-layered product bundling architecture with service orientation shall be designed. [9][7] Using such architectures and Web 2.0, instead of dumping all the available services in the customer's service list, the favourite services, suitable and required services are made available in the customer's personalized service list. [4][7]

"The GenNext banks provide lifecycle wise products and services, from birth till death, under one roof", using needs assessment approach often. [2]

The new Architectures need to be configured which eliminates functional redundancies, provides flexibility to quickly devise new products and services.

The new architectures should be compatible to the existing products and services and also be flexible to new business processes and services.

There are different approaches to build up new architecture to satisfy the customer needs. The one of the best is Line-of-Business (LOB) approach that allows the bank, flexible to migrating solutions, and also readiness levels of the individual business with little impact on other business units.

The next generation of banking based on Web 2.0 fully exhibits the idea of "people-orientation".

With Web 2.0 a customer have personalized online banking experience, and is free to customize his window settings, list interested services in favourites. Moreover it is real-time.

They also integrate many third-party services, such as Google maps, Yahoo stocks, weather forecasts, financial news and so on.

Web 2.0 supports multi-service windows such that user can open several service windows at the same time, and each window supports asynchronous concurrent operation. 
Web 2.0 just adds new services in the service pool when they are released and customer is free to add them to their operation area on demand, but has to accept related service Terms and Conditions for security issues. [4][8]

\section{Delivery Channels of Direct Banking Services}

Banks are able to provide their products and services to their customers anywhere, anytime across different locations with improved transaction realisation and reduced cost. With increasing proliferation of ATMs, Tele-banking, availability of internet and mobile banking facilities, the customer contact points had increased enormously, thereby resulting in increased services to customers.

The application of IT in the banking sector resulted in the development of different concepts of banking such as, e-banking, internet banking, online banking, telephone banking, automated teller machine, universal banking and investment banking, mobile banking etc.

But, the real success of IT in the banking sector depends upon the customer's satisfaction.

Customers are with different requirements. Few prefer human interaction, few open to new channels, few with different preferences with channels, and few in requisite of individual services.

Among, customers who are open to new channels and requisite to individual services, have less time to visit branches and are happy if they are available with $24 \times 7$ banking anywhere, anytime using different delivery channels, with lower cost and time saving involved.

The different delivery channels [5], which are satisfying GenNext customers are:

\section{A. ATM}

ATM is not just to draw cash, rather it supports a wide variety of services like, deposits, account details, mobile recharging. The future ATM, using touch screen interface with customized shortcuts which gives a personalized products and services for the individual customer.

Banks can also make customer to feel that delivery channels provided are user friendly, which may also include talking ATMs, provision of Braille statements, ATMs with Braille keyboards, dedicated service line for the customers with hearing or speech impairment, setting that allow person with low vision to customize the internet. [2] [4]

\section{B. Tele-Banking}

Tele-banking helps customers to interact with bank know more services and products and use of Incorporating Voice Information System (IVR) which is an automatic reply service for customer's general queries.

\section{Online Banking and Mobile Banking}

Online banking provides online transactions, fund transfers, deposits, loan information, which in the present generation mobile banking also facilitating including recharge and bill payments. SMS facilities will be updating customers with new products and services and transaction details.

\section{Mobile Services and Social Media}

These create operational improvements and analytics-based ways of engaging customers. [3]

The nest frontier in direct banking is collection of collaborative technologies-including blogs, wikis, RSS and podcasts, has given birth to social computing, which uses internet to directly connect individuals through their affinity communities and areas of interest. [10]

\section{E. Smart Phones}

It is advancement in mobile technology. They use specialized applications that allow customers to deposit checks by sending images. [3] Smart phones can also be used as payment device instead of credit or debit cards while shopping using Near Field Communication (NFC), radio frequency devices and new payment services and its applications.

\section{F. MIS Server}

In traditional way of banking, even after IT involvement, still the back office work is not automated and still man power is involved in the preparation and submission of various returns. Hence, an MIS server is required to generate returns automatically.

\section{G. Television}

Banking and its services can be made to reach each person through the most popular household means like television i.e., TV banking, which empowers TV viewers to access banking products and service information at the touch of button. [2] 


\section{Proposed Direct Banking Services}

Direct Banking platform is simple and quick to transact on.

- Opening a saving / current / mutual fund account

- Fund transfer / payment messages (Intra-bank and inter-bank)

- Deposit funds

- Personalized Product Bundling

- Quick disposal of loans / investment proposal

- Customer Relationship Management

- Returns reports of the day, weekly, monthly, quarterly, half yearly and annually.

- Organizational bulletin boards may contain: circulars, undesirable parties, hot list, bulletins, missing security items, conditional circulars.

- Management Information System: borrower's profile, branch profile, employee's analysis, products / services profile, business profile of branches.

- Complaint free operations: instead of adopting complaint resolution mechanism, it is best to adopt complain-free operations. The use of SMS, toll-free number, online helpdesk or remote advisor will attract prospective customers and retain existing one. [11] (see figure 2)

Ex: 1. A German Bank allows visitors to its website to schedule a meeting with a branch advisor.

2. A Global Bank allows customers dropping out of an online application process to resume it under the guidelines of a bank representative over phone.

\section{High Level Architecture Of Dbs}

Service Oriented Enterprise Architecture (SOEA) is one of the systematic, modular approaches to design an Enterprise Architecture of Direct Banking Solution. SOEA reduces redundancy and complexity in crucial banking processes such as transactions, channel integration, business processes and services and so on.

The proposed top level architecture of Direct Banking Solution is as shown in figure 3. The architecture comprises of Service Subscribers Layer, Business Solutions Layer, Business Process Layer, Business Service Bus, and Delivery Channel Layer.

\section{A. Service Subscribers Layer}

This layer depicts the users of Banking Solution. Users can be a Prospect, who is not a customer to the bank currently and is a new user, can be Customer, who is already a customer of bank and can be an Employee, who is a bank employee.

\section{B. Business Solutions Layer}

This layer has different business solutions which are used for banking. Proposed architecture has Direct Banking Solution which is integrated with Core Banking Solution. This layer also gives a scope to add new solutions for banking.

Through the layer of solutions, service subscribers are connected to different business processes in retail banking.

\section{Business Process Layer}

This layer has one or more business components like business services; service components, cross cutting services, which are again may be common or specific to service subscribers.

Prospect is a new user, has to first sign-up, register as a new user, submit Identity Verification Documents and accept terms and conditions of the DBS. Many business services are used for each step taken by prospect. Using Cross cutting services, the authentication of the prospect verified and then, the prospect will be accepted as a bank customer.

Customer is provided with an unique username and password, using which customer can enter into banking solution. Customer can

- Modify username and password, and other user details anytime,

- Make use of banking services like, balance enquiry, deposits, transactions etc,

- Interact through discussion forums, FAQs and helpline,

- Choose new service selection, or service extension,

and many more.

Employee can use DBS as an employee or customer. If uses as a customer then, services are same as given for customer. If uses as a employee then, the business services vary depending on the authority given to the employee. Again cross cutting services are used to check the authentication and authorization of the user. In general employee uses services like, 
- Access to bank database,

- Salary details,

- Discussion forums, answering to FAQs,

- Access to customer account on request of customer, etc.

D. Enterprise Service Bus (ESB)

ESB generally supports:

- Message transmission, routing, queuing, and monitoring

- Synchronous, asynchronous, point-to-point transmission

- XML and SOAP messages

Basically it connects layers of SOA.

\section{E. Delivery channels}

Delivery channels layer show all possible mediums through which Direct Banking can be done. Details of delivery channels used in Direct Banking Solution are discussed in Section IV.

User has to choose one of the delivery channels, log-in to the DBS, start banking as per Business processes and services, and log-out to end up banking.

\section{Benefits Of Branchless Banking Solution}

- Branchless Banking solution is a comprehensive solution to acquire, track and service customer through different delivery channels.

- Customers can upload their account opening forms and these can be verified without the intervention of bank staff.

- The increase in online customer base has given banks an opportunity to cross-sell other products.

- Another form of branchless banking could be retail outlets, servicing online and instant loan approvals for purchasing electronic goods, automobiles, popularly known as "in-store banking". [11]

- Ally Financial Inc., American Express Co., and Discover Financial Services, saw their deposits grow from $55 \%$ to $190 \%$ from 2008 to 2011 . [3]

- Only with online banking deposits grow by $70 \%$ since from 2008 to 2011 . Figure 4 shows the gross increase in Mobile payment transactions.

- In Direct banking, using online banking, integrated online application forms, for asset and liability products and multi-channel alerts engine to notify prospects about the status of application across every stage of application processing. [5]

- Direct banking can ensure that products developed for the customers, reach them as per their needs.

VIII. FIGURES

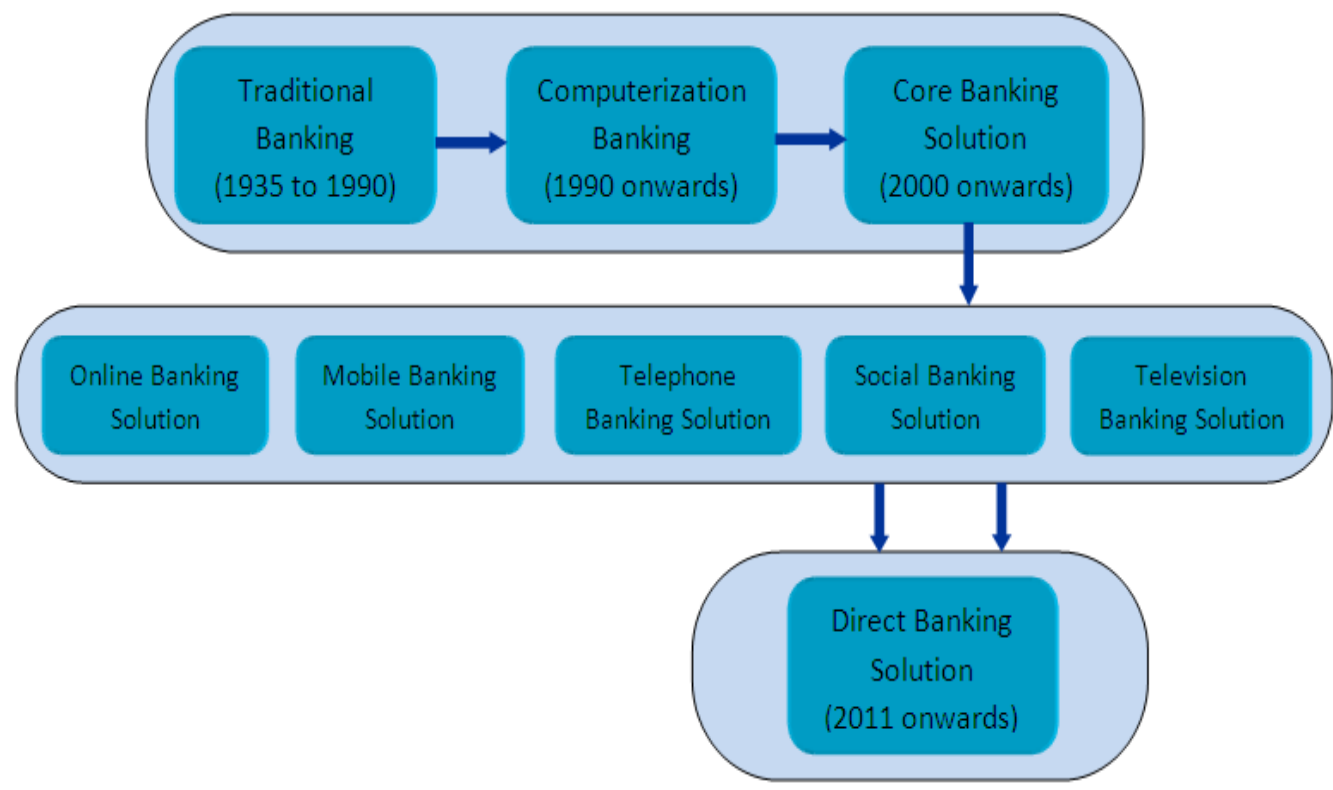

Figure 1: Generations in Banking Enterprise Solutions 


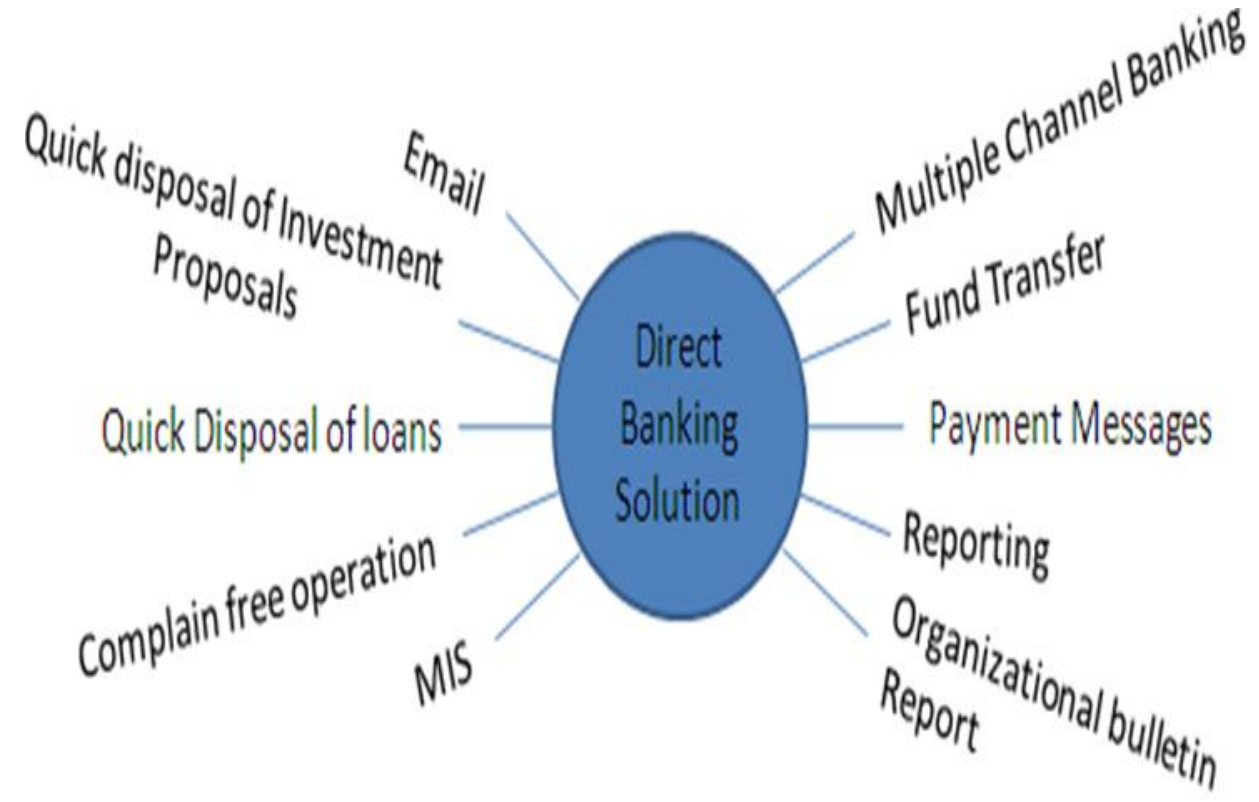

Figure 2: Direct Banking Services

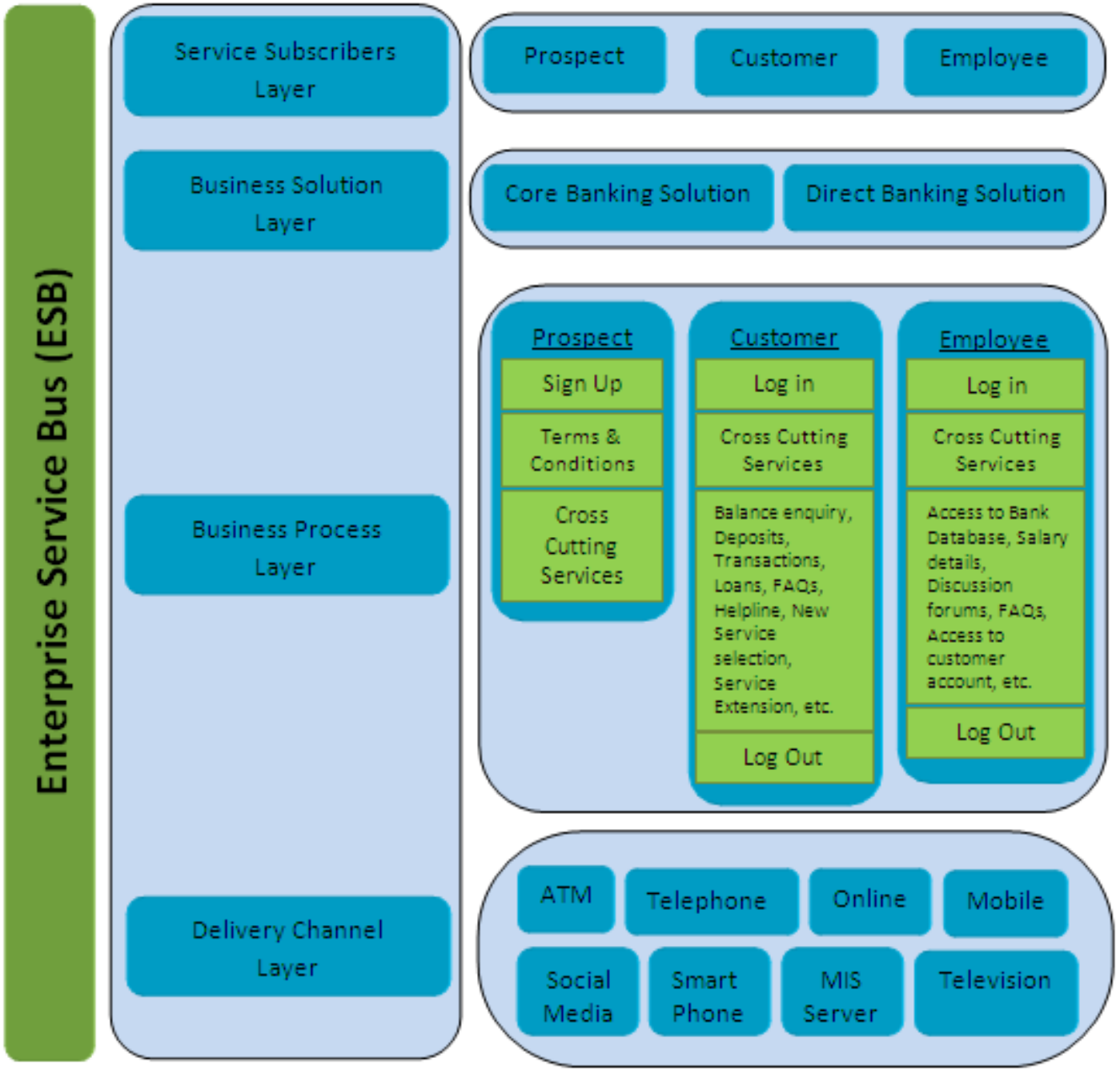

Figure 3: High Level Service Oriented Architecture of Direct Banking Solution 
Mobile Payments Set to Grow

Gross Value of Mobile Payments Transactions, 2009 - 2015

U.S. $\$ M$

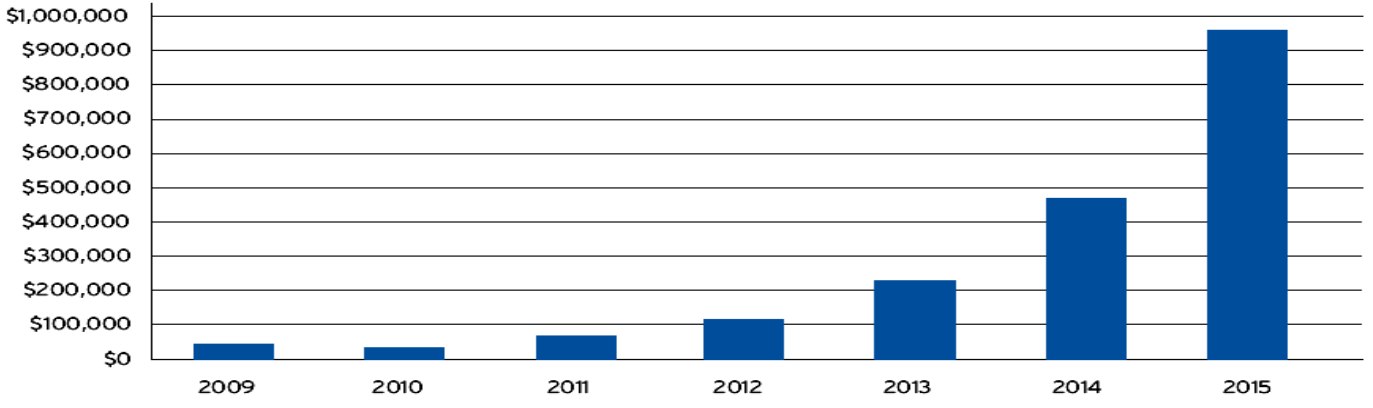

Source: "3Q.20n Global \& Regional Mobile Payments Market Forecast," IE Market Research, 2011.

Figure 4: Depicts the Gross increase in Mobile Payment Transaction (Source [3])

\section{Assumptions / Dependencies}

- The Service Oriented Architecture, Business Processes and Services are subjected to Retail Banking.

- Services represented in paper, few are proposed and few already exist in other Banking Solutions.

- Subscriber's profile and product information is maintained in some database or data warehouse of Retail Banking Solution.

\section{Conclusion}

Although branch network is working in full fledge, branchless banking driven by mobile, internet and other forms of delivery channels makes banks and customers comfortable and satisfied.

Multi-channel network are ensuring that online channels are used as sales vehicle, while branches performing an advisory role. Direct banking supports multi-entity, multi-brand, multi-channel, multi-lingual, and multi-currency.

The market for direct banking will attract more competitors and cost reduction, flexibility and high technical standards will be required to meet the challenges.

The next generation banking provides customer-centric features, giving user an extremely personalized experience while at the same time providing increased intelligence and automation to help banks sell appropriate products and services to their customers.

\section{References}

[1] Ralph Whittle, Conrad Myrick, "Enterprise Business Architecture: The Formal Link between Strategy and Results", White Paper, August.

[2] Dr. K. C. Chakrabarty, Deputy Governeor of RBI, Conference, Institute for Development and Research in Banking Technology(IDRBT) in Collaboration with Union Bank of India, Mumbai, "Beyond Core Banking Solutions-Fast Forward to Banking 2.0", Technical Paper, 18 Feb 2011

[3] Akhil Tandulwadikar, Senior Research Associate, Cognizant Research Center, Cognizant, " Innovative Imperatives in Retail Banking", White Paper, 2012

[4] Xu Ming Chen, Solution Architect, IBM, Shan Jian Hong, Chief Architect, IBM, Shao Yu, Software Engineer, IBM, IBM, "Nextgeneration banking with Web 2.0", White Paper, 01 Dec 2009

[5] Infosys Technologies, "Finacle Direct Banking Solution", White paper, 2012

[6] Eberhardt, A.; Gausmann, O.; Albani, A., On the Move to Meaningful Internet Systems, Workshops, Part I, pp. 763-779 "Case Study - Automating Direct Banking Customer Service Processes with Service Oriented Architecture”, Technical Paper, October/November 2006

[7] Rajashekara V Maiya, Product Manager, Infosys Technologies Limited, Infosys Technologies Limited, Finacle, "Go Direct for Deposits", White Paper, 2009

[8] Danske Bank, "Special Terms and Conditions for Direct Banking", White Paper, 15th Nov 2012

[9] Shreyas Rao, Sowjanya Lakshmi, Salma Banu, "Needs Assessment Approach to Product Bundling in Banking Enterprise", ISSN: 2278-0661, Volume 3, Issue 2, PP 12-17, published in IOSR-JCE, Technical Paper, July-Aug 2012

[10] Jeff Brown, Principal, Deloitte Consulting LLP, David Cox, Director of Research, Scott Griffiths, Senior Consultant, Deloitte Canada, Nita Sanger, Manager, Deloitte Consulting LLP, Deron Weston, Senior Manager, Center of banking Solutions, Deloitte, "Evolving Models of Retail Banking Distribution", White Paper, 2008

[11] Arunnima B S, Finacle - Product Strategy, Infosys Technologies Limited "The Future of Branchless Banking in the United Kingdom" White Paper, 2009

[12] "A New Era of Customer Expectation - Global Banking Survey 2011”, Survey Paper, Ernst and Young, 2011

\section{Author Information}

- Sowjanya Lakshmi A, Assistant Professor, Department of Computer Science and Engineering, Sir M Visvesvaraya Institute of Technology, Bangalore

- Dr B. S. Pradeep, HOD, Department of Computer Science and Engineering, Rajarajeshwari College of Engineering, Bangalore 